\title{
JATIBARANG LANDFILL OF SEMARANG CITY: IS IT POTENTIAL AS THE WATER CONTAMINATION SOURCE?
}

\author{
Heru Hendrayana ${ }^{1}$, Doni Prakasa Eka Putra ${ }^{2}$, Thomas T. Putranto ${ }^{3}$, and Ponhalath \\ Xaixongdeth $^{4}$ \\ 1,2,4 Department of Geological Engineering, Faculty of Engineering, Universitas Gadjah Mada \\ ${ }^{3}$ Department of Geology, University of Diponegoro
}

\begin{abstract}
Like other million inhabitants Cities, Semarang which is the capital city of Central Java Province in Indonesia has a problem in solid waste management. One biggest landfill in the City is the Jatibarang Landfill. The landfill operated since 1992 and currently receives the domestic waste of about 337 ton/day with total volume of about 5.2 million m3 of solid waste. It located on the hill slope of sandstone tertiary rocks and relatively closed to the river of Kreo (which is the main source of drinking water for Semarang City). In order to evaluate the potentiality of landfill as the contamination source to groundwater and surface water, the quality of leachates were analyzed and the hydrogeology of the area was re-studied. Result of the study show that the leachates contain high chloride concentration of about $2600 \mathrm{mg} / \mathrm{L}$ however low concentration of heavymetals. Hydrogeology study show evidence that this leachate is already enters the groundwater system. However its load to the river can be neglected due to the fact that the chloride mass flux derived from the study area was significantly low comparing to the net river loads.
\end{abstract}

Key Word: landfill, water contamination, chloride, groundwater and surface water interaction

\section{Background}

Semarang is a city on the north coast of the island of Java, Indonesia. Approximately 1.5 million people lives in Semarang making it the In- donesia's fifth largest city. Based on the 2005 census, the population in Semarang City was $1,419,478$ with the growth rate of $1.45 \%$. The increment of the population leads to high water demand for both public and domestic consumption while solid wastes are also daily accumulated in the available waste disposal sites which could diminish the quality of both surface and groundwater.

\section{Geology of the study area}

The geomorphology of Jatibarang landfill can be divide into 3 (three) types, which are hilly area, intermountain valley and river valley (see Figure 2). Hilly with steep slope area is located in the west part of research area, which has 26$40 \%$ of slope and elevation about $42-200 \mathrm{~m} \mathrm{msl}$. Intermountain valley area is located in the middle part of research area. This morphology has a concavity form, so all wastes will dump into this area. In this area there is a drain that collects the leachate to transmit it into ponds or Kreo River.

Stratigraphically, the study area consists of tertiary and quaternary rocks. The tertiary rocks are consist of tuffaceous sandstone and conglomerate, and sandy claystone, while the quarternary built by volcanic breccia. The geological structure found in this area generally in the forms of fault and joints. The orientation of fault is relatively west to east and this fault is cutting the tertiary and quaternary rocks. The 

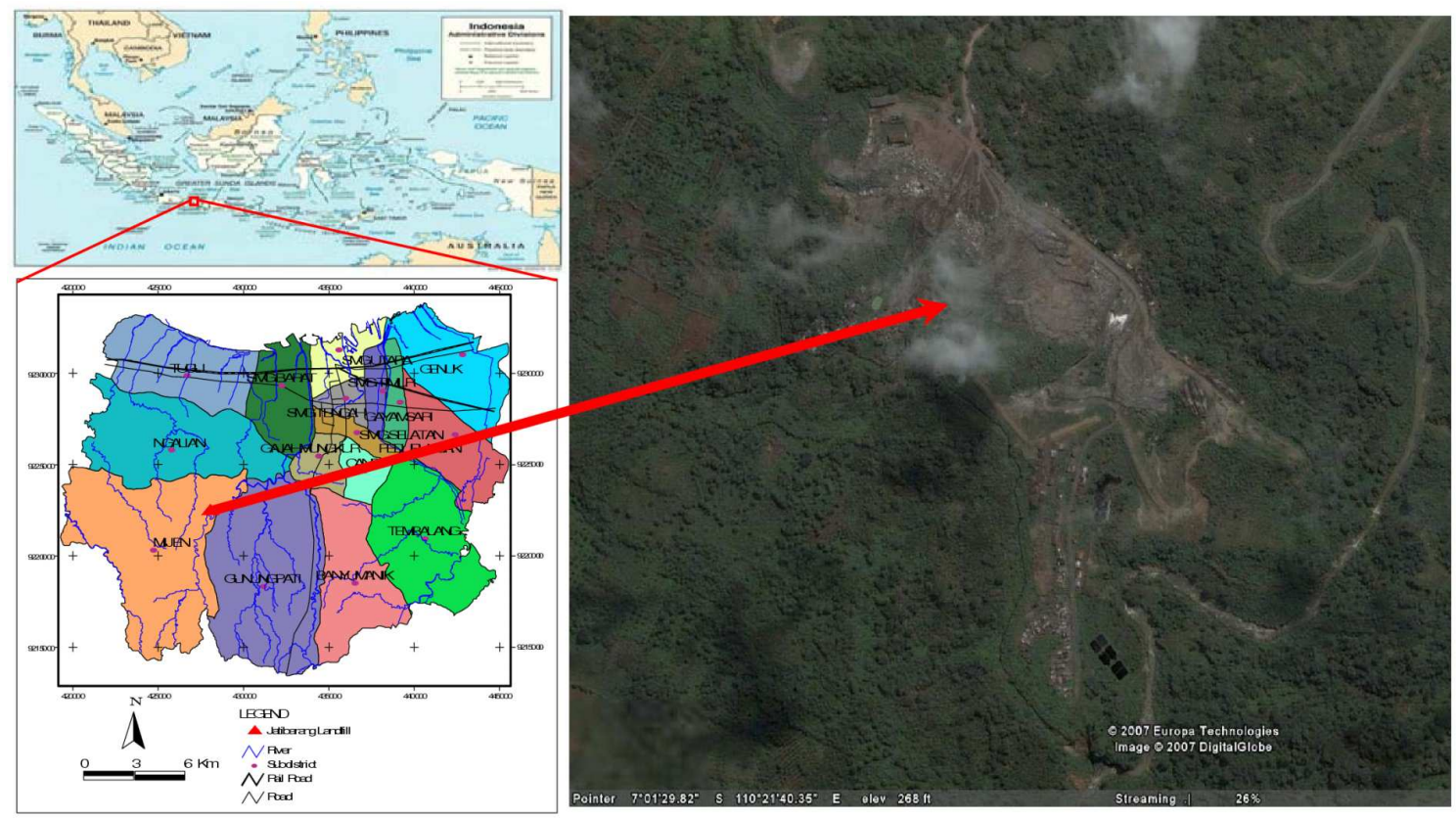

Figure 1: Location of the study area

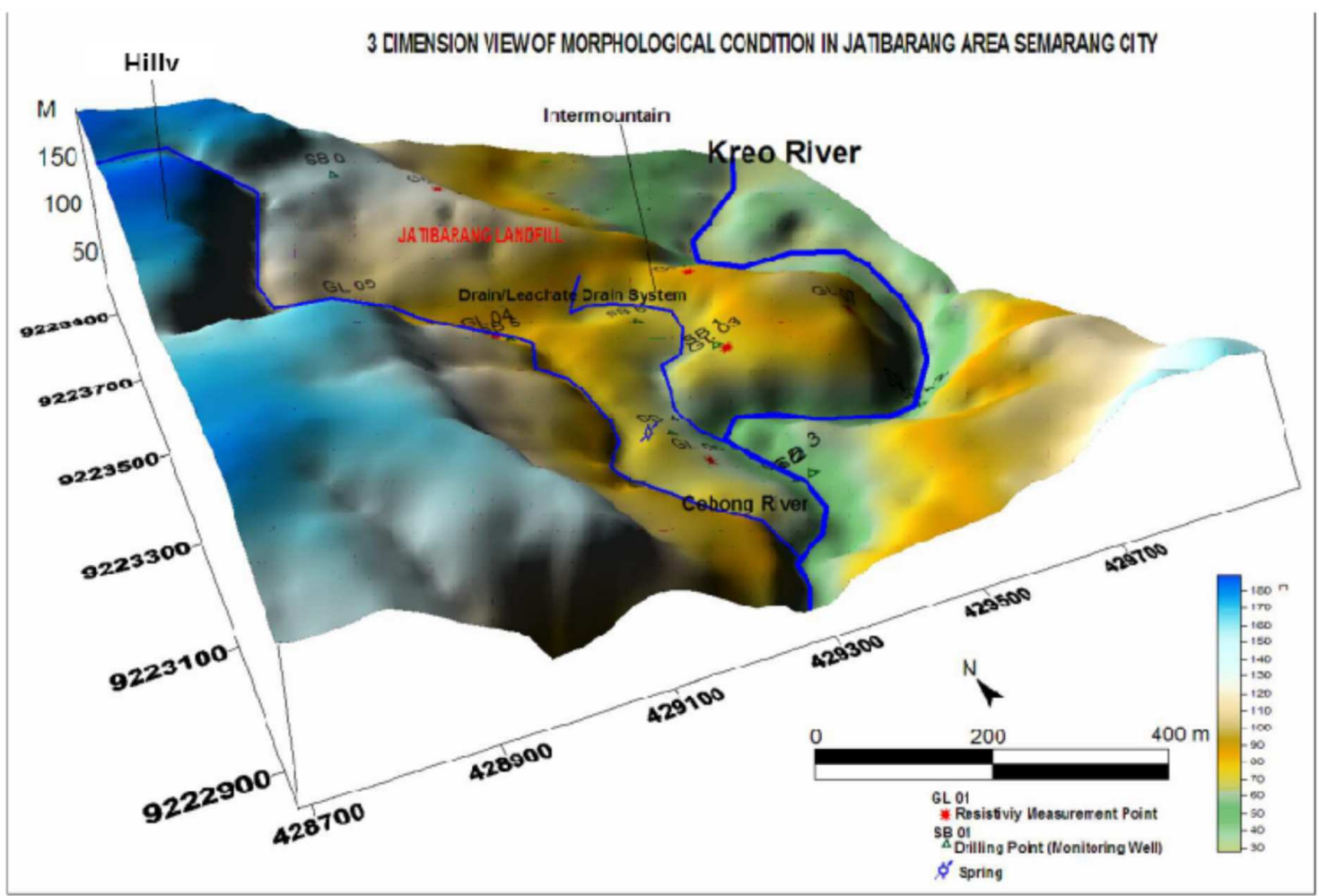

Figure 2: Morphology of the study area (Putranto, 2008) 


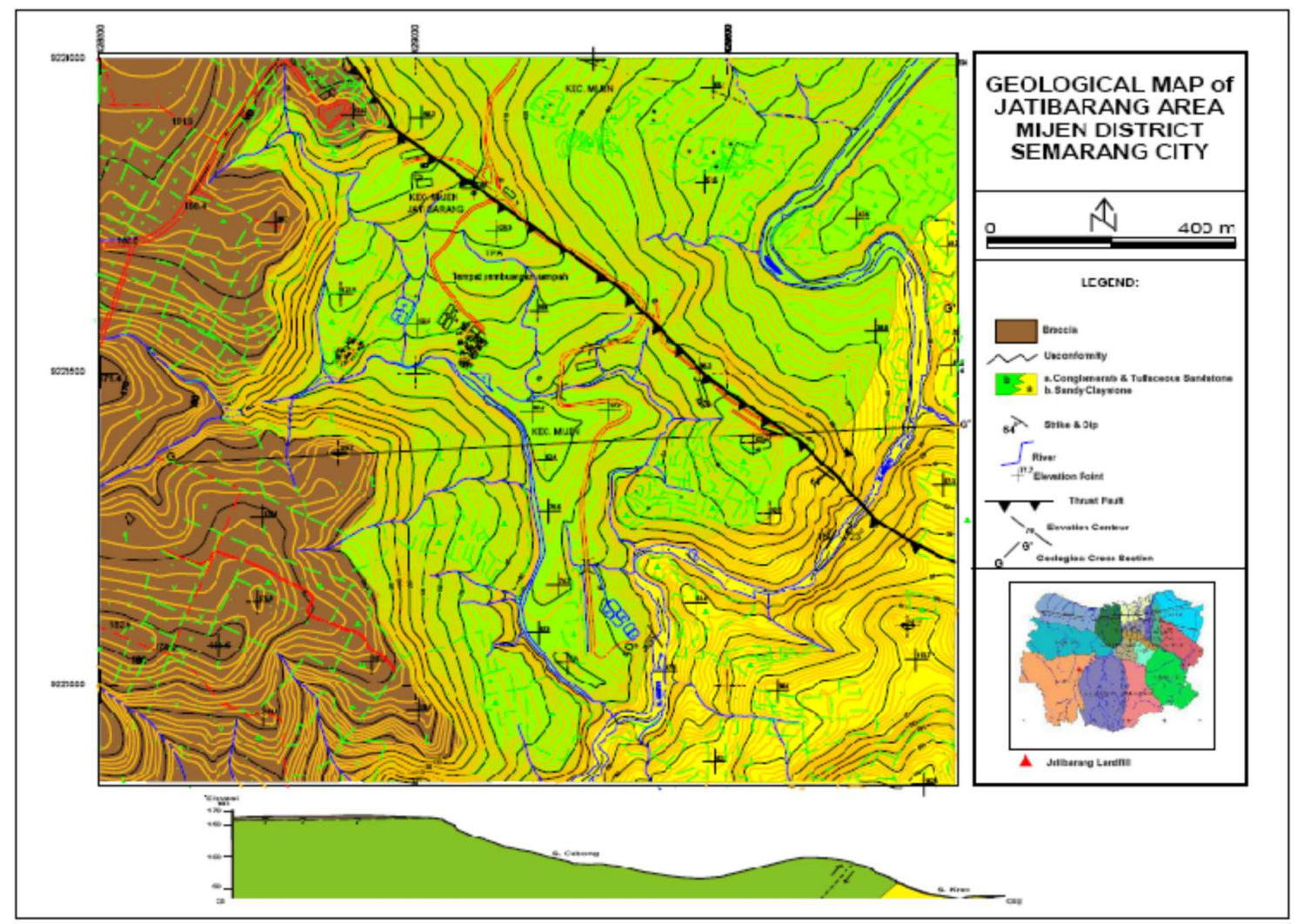

Figure 3: The geological map of the study area (Putranto, 2008)

geological map of the study can be seen on Figure 3 .

\section{Hydrology of the study area}

Based on the climatology data of Semarang City - Geophysics and Meteorological Department for the last 10 years (1998-2007), the average rainfall in the study area is measured to be about $2230 \mathrm{~mm} /$ year with temperature and actual evapotranspiration of about $27.6^{\circ} \mathrm{C}$ and $1372 \mathrm{~mm} /$ year, respectively. Applying empirical equation to estimate the surface runoff, the surface runoff in the study area is about 448 $\mathrm{mm} /$ year. Using water balance concept, the groundwater recharge in this area should be about $410 \mathrm{~mm}$ /year (see Table 1).

\section{Hydrogeology of the study area}

According to geological, hydrological, geoelectric survey result and borehole data, the conceptual model of groundwater flow in Jat-
Table 1: Hydrology Condition in Jatibarang Landfill (1998-2007)

\begin{tabular}{|l|c|}
\hline Hydrological Parameter & Value \\
\hline \hline Average rainfall $(\mathrm{mm} / \mathrm{a})$ & 2230 \\
\hline Average temperature $\left({ }^{\circ} \mathrm{C}\right)$ & 27.6 \\
\hline Actual evapotranspiration $(\mathrm{mm} / \mathrm{a})$ & 1372 \\
\hline Surface run off $(\mathrm{mm} / \mathrm{a})$ & 448 \\
\hline Groundwater Recharge $(\mathrm{mm} / \mathrm{a})$ & 410 \\
\hline
\end{tabular}

ibarang landfill can be developed as shown in Figure 4. Based on the conceptual model, the hydrogeological condition of the study area can be divided into 2 (two) hydrostratigraphy unit which are aquifer and aquiclude. The aquifer consists of sandy claystone and tuffaceous sandstone which builds one shallow unconfined aquifer system that flows in intergranular-pores dan fractures system. Considering the lithological type and the permeability test result, the aquifer is categorized as a poor aquifer. According to level of groundwater depth on each boreholes, groundwater 
flows from north-west part area to the southeast part area (Kreo River). A bottom boundary of aquifer is an aquiclude that consists of tertiary conglomerate rocks which acts as an impermeable layer.

\section{Quality of Jatibarang Landfill Leachate}

The leachate of Jatibarang Landfill contain commonly high concentration of nutrient contaminants such as chloride, phospate, nitrate etc. However heavy metal concentrations including mercury, arsenic, lead, and chromium are very low. The concentration of manganese was found at $4.3 \mathrm{mg} / \mathrm{L}$ while iron and zinc were more than $3.0 \mathrm{mg} / \mathrm{L}$ which are higher than the WHO standard of drinking water $(\leq 0.4 \mathrm{mg} / \mathrm{L}$ for manganese concentration and $\leq 3 \mathrm{mg} / \mathrm{L}$ for iron and zinc (WHO, 2004)). Another important fact is that the leachate contain high phenols of about 12,200 $\mathrm{mg} / \mathrm{L}$.

Detail of physical and chemical compositions of the leachate is shown in Table 2. From this table, at least there are two potential contaminant group may released from the Jatibarang Landfill leachate; nutrients contaminant and organic chemical contaminants. Related to the low concentration of heavy metals, this characteristics are common on the landfill leachate in the Indonesia (Putra, 2007), considering that most of the municipal waste in the Indonesia is dominated by kitchen and market waste and the activities of informal recycling in the landfill are commonly has already taken associated metalsbatteries waste.

\section{Groundwater and Surface Water Qual- ity}

The water quality sampling for groundwater and river water were taken on the groundwater observation wells and Kreo River (see Figure 4). Regarding the groundwater quality samples, only samples taken from SB 06 (distance from landfill about $50 \mathrm{~m}$ ) shows significant contamination of nutrients and phenols. Others groundwater samples show relatively good quality of groundwater. In other hand, the samples from Kreo River show also relatively good river water quality, only some parameter such as $\mathrm{Fe}$ (total) and nitrate $\left(\mathrm{NO}_{3}^{-}\right)$are higher than the national standard of river water quality.

\section{Discussion}

Based on the quality of leachate, it can be concluded that the leachate of Jatibarang landfill is a potential threat to the surrounding natural water quality. Relate to groundwater contamination, high precipitation and groundwater recharge can increase this threat. However, a poor hydraulic conductivity of aquifer below the landfill prove to be a relatively good barrier of contaminant movement in the subsurface. Recently, the leachate contamination to groundwater is estimated to be only located near SB 06 observation wells (more or less $50 \mathrm{~m}$ from the waste area), see Figure 5. Thus input of leachate contamination from groundwater into the Kreo river can be neglected. Therefore, for Kreo river water, the leachate of landfill can enters to the river will be mostly via the landfill drainage system (surface runoff). This conclusion is in agreement with the chloride mass balance calculation of this area conducted by Xaixongdeth (2008), which mentioned that the chloride mass flux to the Kreo river in the Jatibarang landfill area is dominated from the surface run off, however the total chloride mass flux from this study area is very low comparing with the total net of chloride in the Kreo river water (Table 4.

\section{Conclusion}

To sum up, it can be concluded that recently the potential threat of Jatibarang landfill leachate to the Kreo river (which is the main source of drinking water for Semarang City) is very low. However, if the load of waste is increasing with time and there is no groundwater or surface water protection/threatment activities, it can be predicted that in the future, the leachate can enters to the river system not only via the drainage system (surface run off) but also directly from contaminated groundwater system. 


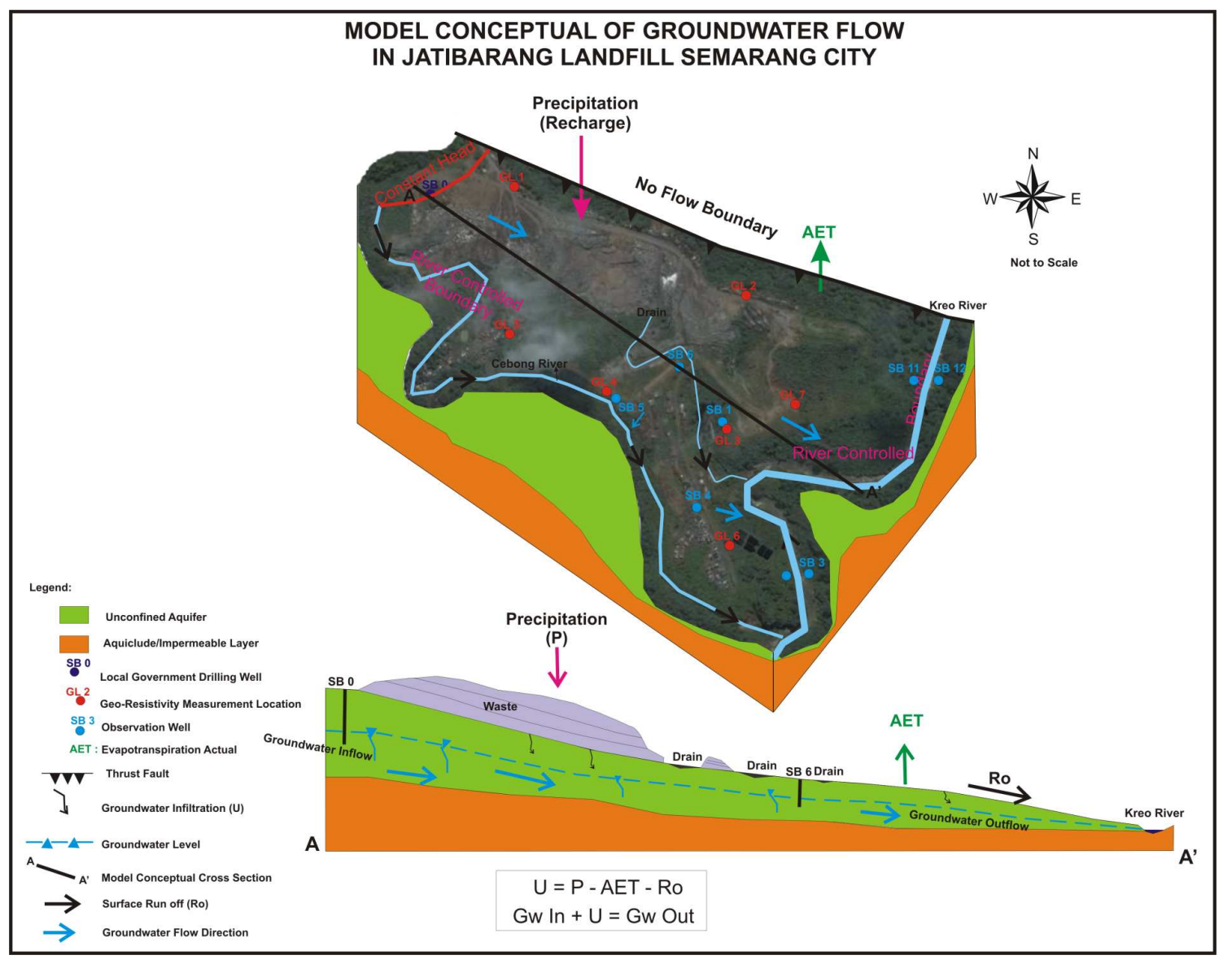

Figure 4: The conceptual model of hydrogeological system of the study area (Putranto, 2008)

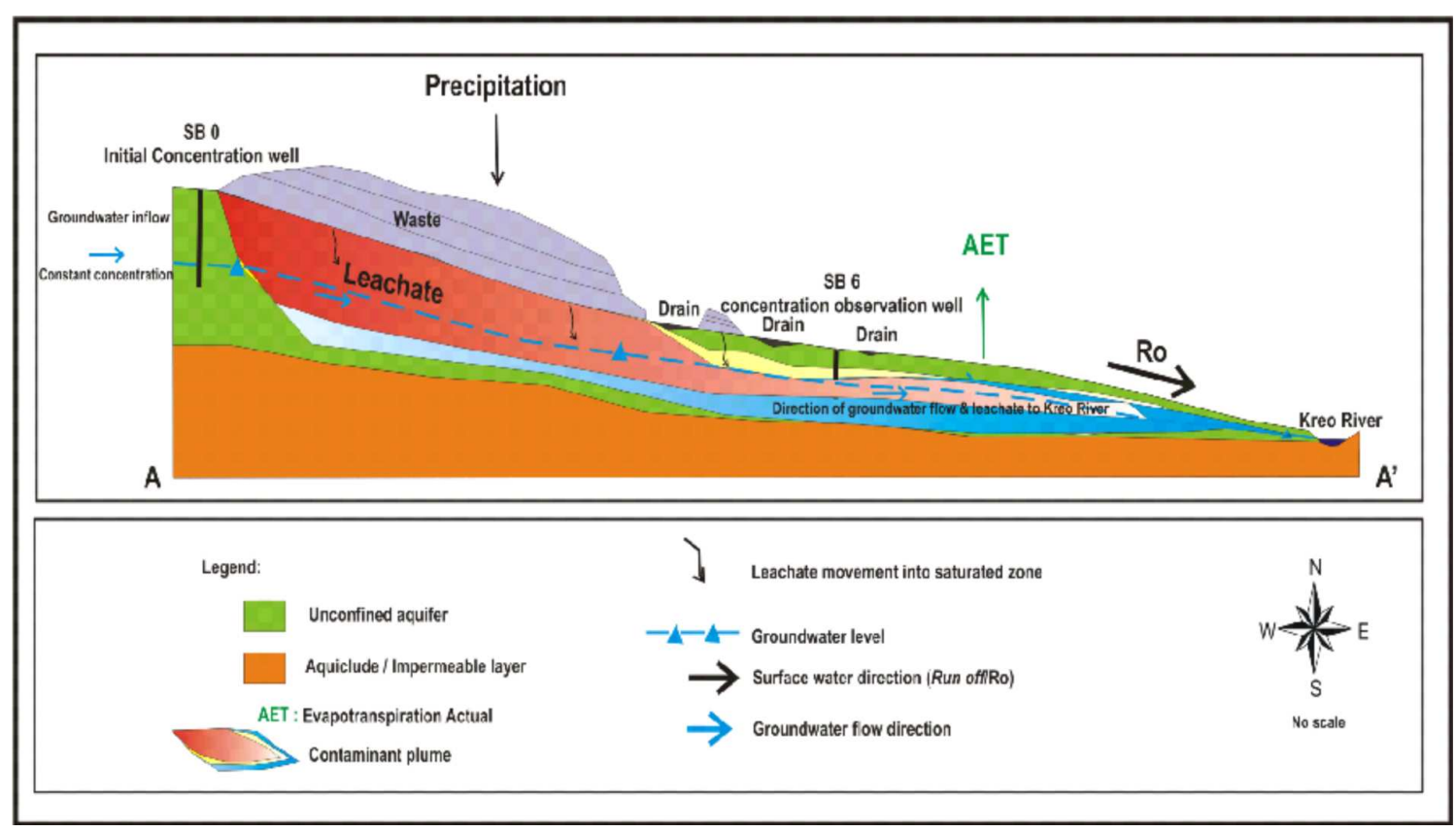

Figure 5: Estimated recent condition of leachate plume in groundwater of the study area 
Table 2: Physical and chemical preperties of Jatibarang landfill leachates

\begin{tabular}{|c|c|c|c|}
\hline NO. & PARAMETER & UNIT & LEACHATE \\
\hline \multicolumn{4}{|c|}{ Physico-Chemical } \\
\hline 1. & Colour & TCU & 24700 \\
\hline 2. & Taste & - & - \\
\hline 3. & Smell & - & No smell \\
\hline 4. & $\mathrm{pH}$ & & 7,5 \\
\hline 5. & Temperature & ${ }^{0} \mathrm{C}$ & 29,7 \\
\hline 6. & Turbidity & NTU & 0.539 \\
\hline 7. & TDS & $\mathrm{mg} / \mathrm{L}$ & $>10000$ \\
\hline \multicolumn{4}{|c|}{ Chemical Content } \\
\hline 1. & $\mathrm{Hg}$ & $\mathrm{mg} / \mathrm{L}$ & ND \\
\hline 2. & As & $\mathrm{mg} / \mathrm{L}$ & ND \\
\hline 3. & $\mathrm{Fe}$ & $\mathrm{mg} / \mathrm{L}$ & 5,47 \\
\hline 4. & $\mathrm{~F}$ & $\mathrm{mg} / \mathrm{L}$ & ND \\
\hline 5. & Hardness & $\mathrm{mg} / \mathrm{L}$ & 26000 \\
\hline 6. & $\mathrm{Cl}$ & $\mathrm{mg} / \mathrm{L}$ & 2612,98 \\
\hline 7. & $\mathrm{Mn}$ & $\mathrm{mg} / \mathrm{L}$ & 4,33 \\
\hline 8. & $\mathrm{NO}_{3}$ & $\mathrm{mg} / \mathrm{L}$ & 256,5 \\
\hline 9. & $\mathrm{NO}_{2}$ & $\mathrm{mg} / \mathrm{L}$ & 6 \\
\hline 10. & $\mathrm{Zn}$ & $\mathrm{mg} / \mathrm{L}$ & 5,335 \\
\hline 11. & $\mathrm{SO}_{4}$ & $\mathrm{mg} / \mathrm{L}$ & 345,1 \\
\hline 12. & $\mathrm{~Pb}$ & $\mathrm{mg} / \mathrm{L}$ & ND \\
\hline 13. & $\mathrm{Cr}(\mathrm{VI})$ & $\mathrm{mg} / \mathrm{L}$ & ND \\
\hline 14. & $\mathrm{Na}$ & $\mathrm{mg} / \mathrm{L}$ & 240,2 \\
\hline 15. & $\mathrm{~K}$ & $\mathrm{mg} / \mathrm{L}$ & 753,83 \\
\hline 16. & Cr Total & $\mathrm{mg} / \mathrm{L}$ & ND \\
\hline 17. & Phenol & $\mathrm{mg} / \mathrm{L}$ & 12,198 \\
\hline 18. & $\mathrm{Mg}$ & $\mathrm{mg} / \mathrm{L}$ & 3400 \\
\hline 19. & $\mathrm{Ca}$ & $\mathrm{mg} / \mathrm{L}$ & 700 \\
\hline 20. & BOD & $\mathrm{mg} / \mathrm{L}$ & 911 \\
\hline 21. & $\mathrm{COD}$ & $\mathrm{mg} / \mathrm{L}$ & 2486 \\
\hline
\end{tabular}

Table 3: Groundwater Quality in the Jatibarang Landfill

\begin{tabular}{|c|c|c|c|c|c|c|c|c|c|c|}
\hline \multirow{2}{*}{ NO. } & \multirow{2}{*}{ PARAMETER } & \multirow{2}{*}{ Unit } & \multicolumn{8}{|c|}{ SAMPLE CODE } \\
\hline & & & SB 0 & SB 02 & SB 03 & SB 04 & SB 05 & SB 06 & SB 11 & SB 12 \\
\hline \multicolumn{11}{|c|}{ Physico-Chemical } \\
\hline 1. & Colour & $\mathrm{TCU}$ & 11 & 19800 & 511 & 92000 & & 18000 & 5230 & 1200 \\
\hline 2. & Taste & - & - & - & - & - & - & - & - & - \\
\hline 3. & Smell & - & $\begin{array}{c}\text { No } \\
\text { smell }\end{array}$ & $\begin{array}{c}\text { No } \\
\text { smell }\end{array}$ & $\begin{array}{c}\text { No } \\
\text { smell }\end{array}$ & $\begin{array}{c}\text { No } \\
\text { smell } \\
\end{array}$ & $\begin{array}{c}\text { No } \\
\text { smell } \\
\end{array}$ & $\begin{array}{c}\text { No } \\
\text { smell }\end{array}$ & $\begin{array}{c}\text { No } \\
\text { smell }\end{array}$ & $\begin{array}{c}\text { No } \\
\text { smell }\end{array}$ \\
\hline 4. & $\mathrm{pH}$ & - & 7,44 & 8,02 & 7,88 & 7,64 & 7,43 & 7,15 & 7,72 & 7,47 \\
\hline 5. & Temperature & ${ }^{0} \mathrm{C}$ & 27,4 & 27,5 & 27,4 & 27,9 & 27,9 & 27,9 & 30,1 & 30 \\
\hline 6. & Turbidity & NTU & 0.035 & 19 & 15,8 & 23,4 & 15,4 & 157 & 34,8 & 6,75 \\
\hline 7. & TDS & $\mathrm{Mg} / \mathrm{L}$ & 375 & 327 & 320 & 511 & 631 & 13500 & 155 & 250 \\
\hline \multicolumn{11}{|c|}{ Chemistry } \\
\hline 1. & $\mathrm{Hg}$ & $\mathrm{Mg} / \mathrm{L}$ & ND & ND & ND & ND & ND & ND & ND & ND \\
\hline 2. & As & $\mathrm{Mg} / \mathrm{L}$ & ND & ND & ND & ND & ND & ND & ND & ND \\
\hline 3. & $\mathrm{Fe}$ & $\mathrm{Mg} / \mathrm{L}$ & ND & 1,01 & 6,26 & ND & 0,3 & 29,4 & 4,4 & ND \\
\hline 4. & $\mathrm{~F}$ & $\mathrm{Mg} / \mathrm{L}$ & ND & ND & ND & ND & ND & ND & ND & ND \\
\hline 5. & Hardness & $\mathrm{Mg} / \mathrm{L}$ & 274 & 216 & 216 & 214 & 170 & 2800 & 70 & 70 \\
\hline 6. & $\mathrm{Cl}$ & $\mathrm{Mg} / \mathrm{L}$ & 45,55 & 20,38 & 22,17 & 97,68 & 171,99 & 1765 & 181,7 & 24,27 \\
\hline 7. & $\mathrm{Mn}$ & $\mathrm{Mg} / \mathrm{L}$ & ND & ND & ND & 1,91 & 1,09 & 24,4 & 0,87 & ND \\
\hline 8. & $\mathrm{NO}_{3}$ & $\mathrm{Mg} / \mathrm{L}$ & 5,48 & 0,6 & 2,62 & 11,53 & 0,84 & 68,7 & 8,42 & 11,76 \\
\hline 9. & $\mathrm{NO}_{2}$ & $\mathrm{Mg} / \mathrm{L}$ & ND & ND & ND & 0,2 & 0,08 & ND & 0,98 & 0,12 \\
\hline 10. & $\mathrm{Zn}$ & $\mathrm{Mg} / \mathrm{L}$ & 0,181 & 0,077 & 0,552 & 0,855 & 0,111 & 7,628 & 0,332 & 0,487 \\
\hline 11. & $\mathrm{SO}_{4}$ & $\mathrm{Mg} / \mathrm{L}$ & 11,92 & 3,44 & 42,07 & 2,31 & 18,62 & 120,2 & 72,2 & 31,27 \\
\hline 12. & $\mathrm{~Pb}$ & $\mathrm{Mg} / \mathrm{L}$ & 0,2 & ND & 0,042 & ND & 0,233 & 0,567 & 0,1 & 0,133 \\
\hline 13. & $\mathrm{Cr}(\mathrm{VI})$ & $\mathrm{Mg} / \mathrm{L}$ & ND & ND & ND & ND & ND & ND & ND & ND \\
\hline 14. & $\mathrm{Na}$ & $\mathrm{Mg} / \mathrm{L}$ & 13,28 & 19,21 & 35,88 & 25,57 & 28,68 & 876,05 & 53,71 & 83,08 \\
\hline 15. & $\mathrm{~K}$ & $\mathrm{Mg} / \mathrm{L}$ & 5,99 & 8,44 & 9,10 & 18,04 & 10,61 & 1599 & 12,75 & 11,4 \\
\hline 16. & Cr Total & $\mathrm{Mg} / \mathrm{L}$ & ND & ND & ND & ND & ND & ND & ND & ND \\
\hline 17. & Phenol & $\mathrm{Mg} / \mathrm{L}$ & $\mathrm{ND}$ & $\mathrm{ND}$ & ND & 0,14 & 0,11 & 9,03 & 0,067 & 0,06 \\
\hline 18. & $\mathrm{Mg}$ & $\mathrm{Mg} / \mathrm{L}$ & 28 & 36 & 37 & 17 & 18 & 336 & 5 & 13 \\
\hline 19. & $\mathrm{Ca}$ & $\mathrm{Mg} / \mathrm{L}$ & 62 & 26 & 25 & 57 & 38 & 560 & 20 & 7 \\
\hline
\end{tabular}


Table 4: Kreo river water quality

\begin{tabular}{|c|c|c|c|c|c|}
\hline \multirow{2}{*}{ NO. } & \multirow{2}{*}{ PARAMETER } & \multirow{2}{*}{ UNIT } & \multicolumn{3}{|c|}{ Sample Code } \\
\hline & & & R1 & R2 & $\mathbf{R 3}^{*}$ \\
\hline \multicolumn{6}{|c|}{ Physico-chemical } \\
\hline 1. & Colour & TCU & 238 & 228 & 332 \\
\hline 2. & Smell & - & No smell & No smell & No smell \\
\hline 3. & $\mathrm{pH}$ & & 8,25 & 8,12 & 8,10 \\
\hline 4. & Temperature & ${ }^{\circ} \mathrm{C}$ & 27,8 & 27,8 & 27,8 \\
\hline 5. & Turbidity & NTU & 2,74 & 4,16 & 4,66 \\
\hline 6. & TDS & $\mathrm{Mg} / \mathrm{L}$ & 134 & 135 & 177 \\
\hline \multicolumn{6}{|c|}{ Chemical content } \\
\hline 1. & $\mathrm{Hg}$ & $\mathrm{Mg} / \mathrm{L}$ & ND & ND & ND \\
\hline 2. & As & $\mathrm{Mg} / \mathrm{L}$ & ND & ND & ND \\
\hline 3. & $\mathrm{Fe}$ & $\mathrm{Mg} / \mathrm{L}$ & 2 & 1,87 & 1,54 \\
\hline 4. & $\mathrm{~F}$ & $\mathrm{Mg} / \mathrm{L}$ & 0 & 0 & 0 \\
\hline 5. & Hardness & $\mathrm{Mg} / \mathrm{L}$ & 76 & 78 & 74 \\
\hline 6. & $\mathrm{Cl}$ & $\mathrm{Mg} / \mathrm{L}$ & 20,98 & 25,77 & 28,77 \\
\hline 7. & $\mathrm{Mn}$ & $\mathrm{Mg} / \mathrm{L}$ & $\mathrm{ND}$ & ND & ND \\
\hline 8. & $\mathrm{NO}_{3}$ & $\mathrm{Mg} / \mathrm{L}$ & 11,42 & 10,53 & 11,73 \\
\hline 9. & $\mathrm{NO}_{2}$ & $\mathrm{Mg} / \mathrm{L}$ & 0,14 & 0,22 & 0,19 \\
\hline 10. & $\mathrm{Zn}$ & $\mathrm{Mg} / \mathrm{L}$ & 0,01 & 0,02 & 0,01 \\
\hline 11. & $\mathrm{SO}_{4}$ & $\mathrm{Mg} / \mathrm{L}$ & 64,39 & 62,07 & 66,58 \\
\hline 12. & $\mathrm{~Pb}$ & $\mathrm{Mg} / \mathrm{L}$ & ND & ND & ND \\
\hline 13. & $\mathrm{Cr}(\mathrm{VI})$ & $\mathrm{Mg} / \mathrm{L}$ & ND & ND & ND \\
\hline 14. & $\mathrm{Na}$ & $\mathrm{Mg} / \mathrm{L}$ & 15,669 & 9,819 & 10,334 \\
\hline 15. & $\mathrm{~K}$ & $\mathrm{Mg} / \mathrm{L}$ & 2,364 & 17,6 & 2,453 \\
\hline 16. & Cr Total & $\mathrm{Mg} / \mathrm{L}$ & ND & ND & ND \\
\hline 17. & Phenol & $\mathrm{Mg} / \mathrm{L}$ & ND & ND & ND \\
\hline 18. & $\mathrm{Mg}$ & $\mathrm{Mg} / \mathrm{L}$ & 8,64 & 8,16 & 7,68 \\
\hline 19. & $\mathrm{Ca}$ & $\mathrm{Mg} / \mathrm{L}$ & 16 & 17,6 & 16,8 \\
\hline 20. & DO & $\mathrm{Mg} / \mathrm{L}$ & 7,36 & 7,82 & 7,22 \\
\hline
\end{tabular}

\section{References}

Putra, D.P.E (2007): The Impact of Urbanization on Groundwater Quality, A Case Study in Yogyakarta City - Indonesia, Mitteilungen zur Ingenieurgeologie und Hydrogeologie, Heft 96, 148 S, Okt 2007, Herausgegeben vom Lehrstuhl fuer Ingenieurgeologie und Hydrogeologie, Univ.-Prof. Dr. R. Azzam, RWTH Aachen, Germany.

Putranto, T.T (2008): Pemodelan Pergerakan Kontaminan dalam Airtanah di TPA Jatibarang, Kota Semarang, Tesis, Program Pasca Sarjana, Jurusan Teknik Geologi, Fakultas Teknik, Universitas Gadjah Mada (unpublished).

Putranto, T.T, Hendrayana, H., \& Putra, D.P.E (2008): Pemodelan Pergerakan Kontaminan dalam Airtanah di TPA Jatibarang, Kota Semarang, dalam: Prosiding Pertemuan Ilmiah
Tahunan IAGI ke 37, 26 - 30 Agustus 2008, Hotel Horison, Bandung.

WHO (2004): Guidelines for Drinking Water Quality, Vol.1, 3rd Ed., World Health Organization, Geneva, 2004.

Xaixongdeth, P. (2008): Hydrogeochemical Interaction Of Groundwater And Surface Water in Jatibarang Landfill Area, Semarang City, Indonesia, Thesis, Graduate Program, Geological Engineering Department, Faculty of Engineering, Gadjah Mada University (unpublished).

Xaixongdeth, P. Hendrayana, H., Putra, D.P.E., Jinno, K (2008): Groundwater Chloride Mass Transport in Jatibarang Landfill Area, Semarang, Central Java, Indonesia, in Proceeding of Annual Convention of 33rd The Indonesian Association of Geophysics, Hyatt Regency Bandung, November 3-5, 2008 . 